E3S Web of Conferences 1, 17003 (2013)

DOI: $10.1051 / \mathrm{e} 3$ sconf/20130117003

(c) Owned by the authors, published by EDP Sciences, 2013

\title{
Monitoring of gaseous elemental mercury in central Antarctica at Dome Concordia
}

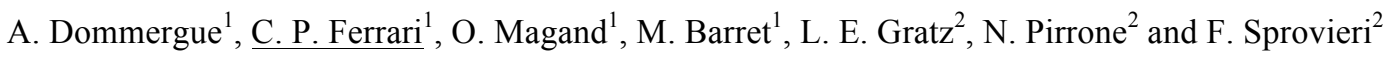 \\ ${ }^{1}$ UJF - Grenoble 1 / CNRS, Laboratoire de Glaciologie et Géophysique de l'Environnement (LGGE) UMR 5183, \\ Grenoble, F-38041, France dommergue@lgge.obs.ujf-grenoble.fr \\ ${ }^{2}$ CNR Institute of Atmospheric Pollution Research, Rende, Italy
}

\begin{abstract}
Within the framework of the Global Mercury Observation System (GMOS), we are monitoring gaseous elemental mercury $(\operatorname{Hg}(0))$ at the Dome Concordia Station to improve our understanding of atmospheric Hg in the Antarctic atmosphere. This French-Italian facility is located in one of the coldest places on the planet and is situated on the vast Antarctic Plateau at an elevation of $3320 \mathrm{~m}$. Continuous measurements began on December 7, 2011 and are ongoing. The median value calculated over the period $(\mathrm{n}=24506)$ is approximately $0.9 \mathrm{ng} / \mathrm{m}^{3}$ and values range from $<0.1 \mathrm{ng} / \mathrm{m}^{3}$ up to $2.3 \mathrm{ng} / \mathrm{m}^{3}$. Preliminary results suggest that the Antarctic atmospheric boundary layer is a very reactive place during the periods when sunlight is present. A combination of fast and efficient oxidation processes with snow photochemistry lead to a dynamic record of $\operatorname{Hg}(0)$ unlike any other location. Our improved understanding of these processes will help to better constrain the cycle of $\mathrm{Hg}$ in the Southern Hemisphere.
\end{abstract}

Key words: gaseous elemental mercury, Antarctica, Polar Regions, GMOS

\section{Introduction}

Gaseous elemental mercury $(\operatorname{Hg}(0))$ is the most abundant form of $\mathrm{Hg}$ in the troposphere with a background concentration of approximately $1.5 \mathrm{ng} . \mathrm{m}^{-3}$ in the Northern Hemisphere and $1.1 \mathrm{ng} . \mathrm{m}^{-3}$ in the Southern Hemisphere (Sprovieri et al., 2010). $\mathrm{Hg}(0)$ is also thought to have a tropospheric residence time of about 6-24 months, allowing it to be globally transported far from its emission sources (Selin et al., 2007). Oxidized Hg compounds, such as the operationally defined reactive gaseous $\mathrm{Hg}$ (RGM) and $\mathrm{Hg}$ associated with airborne particulate matter $(\mathrm{HgP})$ are normally found at much lower concentrations (in the pg. $\mathrm{m}^{-3}$ range) in the troposphere. The atmospheric lifetime of $\operatorname{Hg}(0)$ dramatically decreases to a few hours during fast oxidation processes involving bromine radicals as observed in various locations including lower latitudes (Obrist et al., 2011), the Arctic (Steffen et al., 2008) and the Antarctic (Brooks et al., 2008b, Ebinghaus et al., 2002, Sprovieri et al., 2002).

To date, research activities dealing with $\mathrm{Hg}$ in Polar Regions have focused primarily on the Northern Hemisphere troposphere, whereas the atmospheric cycling of $\mathrm{Hg}$ in the Antarctic, including the impact of the Antarctic continent and its influence on the global geochemical cycle of $\mathrm{Hg}$, have not been explored in great detail (Dommergue et al., 2010). The Antarctic, which is seven times larger than Greenland, has been considered a chemically-inactive and cold sink where atmospheric species, including $\mathrm{Hg}$, are buried in the ice-cap. However, recent studies have shown that the inner plateau is a highly oxidizing area (Eisele et al., 2008) and that some compounds, such as nitrogen in the form of nitrate, may undergo multiple recycling between the snow surface and the overlying atmosphere (Davis et al., 2008).

In particular, the atmospheric $\mathrm{Hg}$ behavior on the high altitude Antarctic Plateau (several millions of $\mathrm{km}^{2}$ with an elevation above $2 \mathrm{~km}$ ) is an open and vast field of research. To our best knowledge, two atmospheric studies with modern on-line instruments report an unusual $\mathrm{Hg}$ cycle at South Pole $\left(90^{\circ} \mathrm{S}\right)$ (Brooks et al., $2008 \mathrm{a})$ and at Dome Concordia $\left(75^{\circ} \mathrm{S}\right)$ (Dommergue et al., 2012). Brooks et al. (2008a) measured high levels of oxidized $\mathrm{Hg}$ species and they reported high $\mathrm{Hg}$ deposition on snow surfaces. Previously, significant filterable $\mathrm{Hg}$ was also reported (Arimoto et al., 2004). The detailed mechanisms and the compounds involved in this reactivity remains uncertain. These phenomena have to be further explored with longer data sets in order to provide new data for the comprehension of the global atmospheric $\mathrm{Hg}$ reactivity and to improve reactivity and 
deposition models (Selin et al., 2007). Atmospheric measurements on the Antarctic ice-cap will also be useful to improve our interpretation of ice-core data (Jitaru et al., 2009, Vandal et al., 1993).

Fig.1 Dome Concordia Station in Antarctica (red dot).

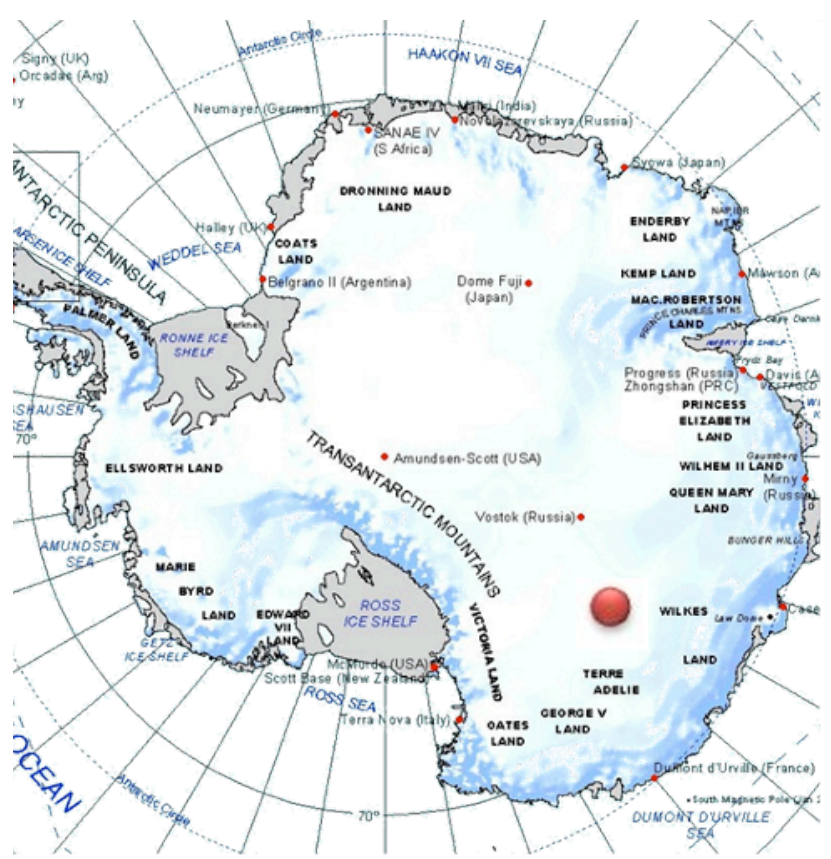

To further develop our understanding of the physico-chemical processes involving $\mathrm{Hg}$ over this large area of the planet, we began atmospheric monitoring $\mathrm{Hg}(0)$ at Dome Concordia (DC) Station $\left(75^{\circ} \mathrm{S}, 123^{\circ} \mathrm{E}, 3320 \mathrm{~m}\right.$ above sea level) in December 2011. This monitoring program is an important contributor to the Global Monitoring Observation System (GMOS) ground-based monitoring network.

\section{Materials and Methods}

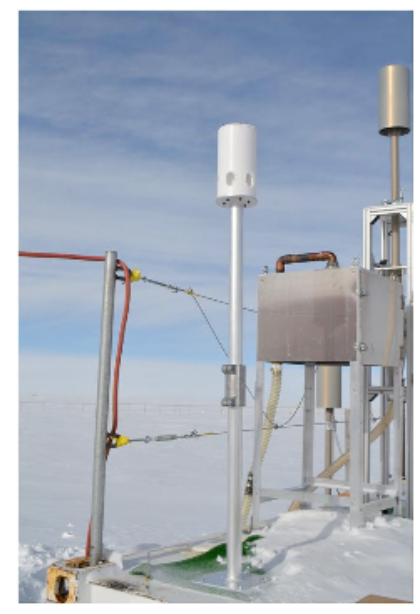

Fig. 2. Sampling

system at DC

Measurements at the French-Italian base of Dome Concordia Station $\left(75^{\circ} 06^{\prime} \mathrm{S}, 123^{\circ} 20^{\prime} \mathrm{E}, 3320 \mathrm{~m}\right.$ above sea level) began in December 2011. Dome Concordia Station (DC) is located on the large antarctic plateau, $1100 \mathrm{~km}$ away from the nearest coast of East Antarctica. $\mathrm{DC}$ is one of the coldest places the planet. The mean anuual temperature is $-50.8^{\circ} \mathrm{C}$, and the minimum temperature ever recorded was $-84.4^{\circ} \mathrm{C}$. DC is very dry with precipitation of about $2-10 \mathrm{~cm}$ of snow per year. Sun is permanent from November to February and the full night is from May to mid-August.

To minimize contamination from the station, $\operatorname{Hg}(0)$ measurements are performed in a separate clean atmospheric laboratory, which is located 800 meters upwind and south of the DC station. We use a Tekran 2537A analyzer for the continuous monitoring of $\mathrm{Hg}(0)$ with a 5-min sampling resolution. $\operatorname{Hg}(0)$ in the pre-filtered air stream (soda lime trap and $0.2 \mu \mathrm{m}$ PTFE filter) is alternatively collected on two gold cartridges at a flow rate of $1.0 \mathrm{~L} \mathrm{~min}^{-1}$. The analyzer is calibrated every $25 \mathrm{~h}$ using an internal automatic permeation source. The inlet system is approximately $5 \mathrm{~m}$ above the snow surface on the roof top of the "glacio" shelter. It is protected by a PFA frame in order to avoid the formation of frost inside the line and on the inlet filter.

\section{Results and Discussion}

The first 5 months of data are presented on Fig 3. Various logistical problems interrupted the record. $\mathrm{Hg}(0)$ data are distributed around a median value of $0.9 \pm 0.1$ $\mathrm{ng} / \mathrm{m}^{3}$ with a range of $<0.1 \mathrm{ng} / \mathrm{m}^{3}$ to about $2.3 \mathrm{ng} / \mathrm{m}^{3}$. The range of data is coherent with previous data measured in January 2009 at DC (Dommergue et al., 2012). The median concentration is significantly lower than measurements made on the Greenland ice cap (Faïn et al., 2008) but comparable to values retrieved both at coastal sites of Antarctica such as Neumayer Station $(0.99 \pm 0.27$ ng. $\mathrm{m}^{-3}$ (Ebinghaus et al., 2002, Temme et al., 2003), Terra Nova Bay $\left(0.9 \pm 0.3\right.$ ng.m ${ }^{-3}$ (Sprovieri et al., 2002)), McMurdo (1.20 \pm 1.08 ng.m ${ }^{-3}$ (Brooks et al., 2008b) and the continental South Pole station $0.54 \pm 0.19 \mathrm{ng} . \mathrm{m}^{-3}$ (Brooks et al., 2008a).

From December to March we recorded a very dynamic pattern. We believe that the reactivity is linked to solar radiation and photochemistry because the termination of this behavior is consistent with the end of the permanent sun period. As an example, Figure 4 illustrates the daily reactivity observed in December. Maxima are generally recorded at noon (local time) and are strongly influenced by snow emissions. The snowpack is known to emit photoreduced $\mathrm{Hg}(\mathrm{II})$ as $\mathrm{Hg}(0)$ (Dommergue et al., 2007). In a previous study (Dommergue et al., 2012), we showed that $\mathrm{Hg}(0)$ was produced in the snowpack at DC. At nights, $\operatorname{Hg}(0)$ levels are very low and we assume that $\operatorname{Hg}(0)$ is oxidized in the atmospheric boundary layer at DC. The oxidant is unknown yet, but it is likely to be a rapid mechanism such as the one observed during Atmospheric Mercury Depletion Events in the Arctic (Steffen et al., 2008) 


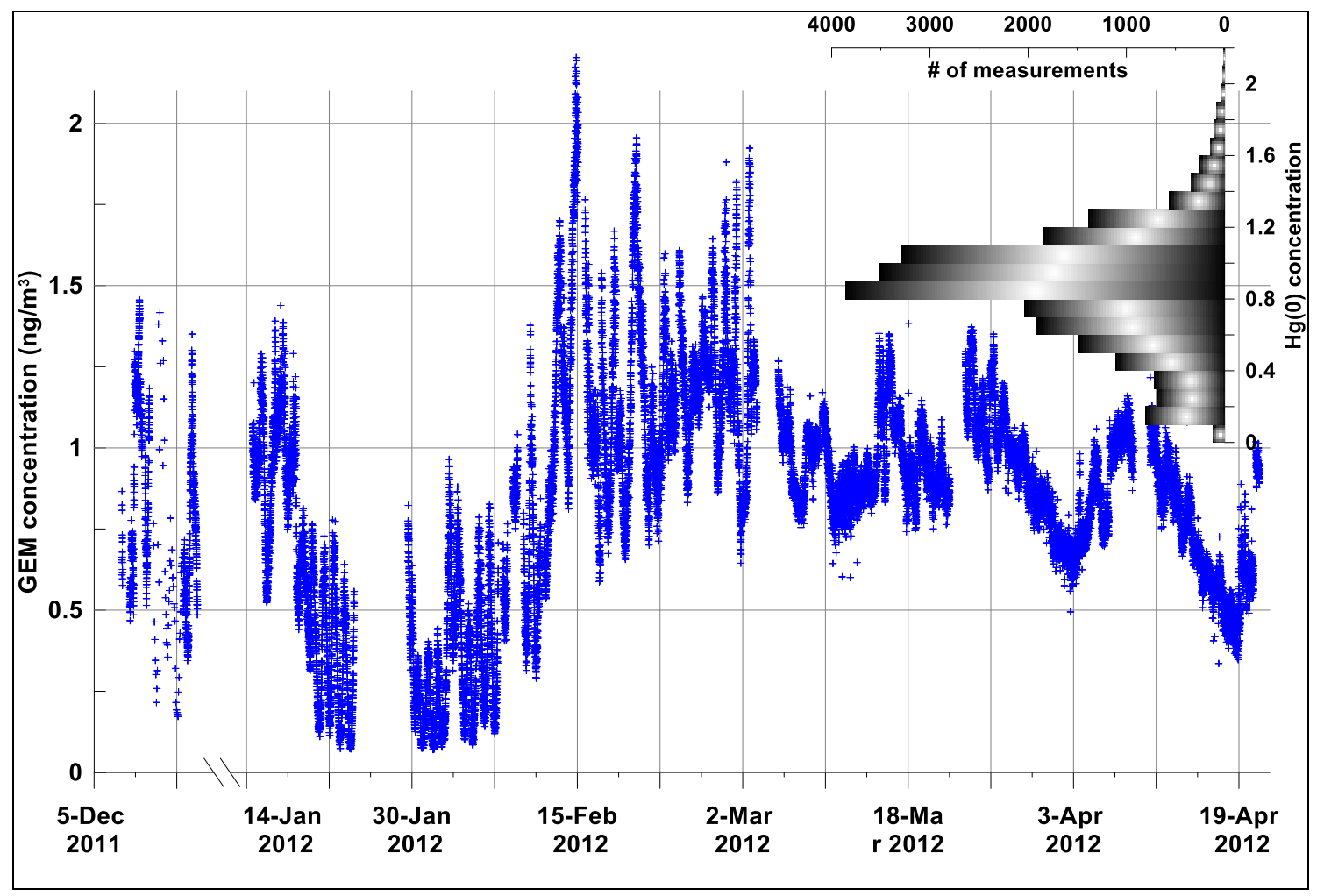

Fig. 3: Time series (local time) of 5-min $\operatorname{Hg}(0)$ data at DC. In the right corner, we represented the data distribution.

While the analysis of the data remains preliminary, we noticed two surprising periods from mid-January to the $1^{\text {st }}$ week of February (period A), and from mid-February to beginning of March (period B). Period A showed very low average values (around $0.3 \mathrm{ng} / \mathrm{m}^{3}$ ) indicating a long lasting period with almost permanent oxidation processes of $\mathrm{Hg}(0)$. Such phenomenon has never been observed at any other site in the world. It could lead to the deposition of large amounts of $\mathrm{Hg}$ (II) on the snow surface. However the subsequent period B showed very high $\operatorname{Hg}(0)$ values, suggesting that reemission processes prevailed during that period. We think that $\mathrm{Hg}(\mathrm{II})$ deposited during period $\mathrm{A}$ is reemitted from the snowpack.

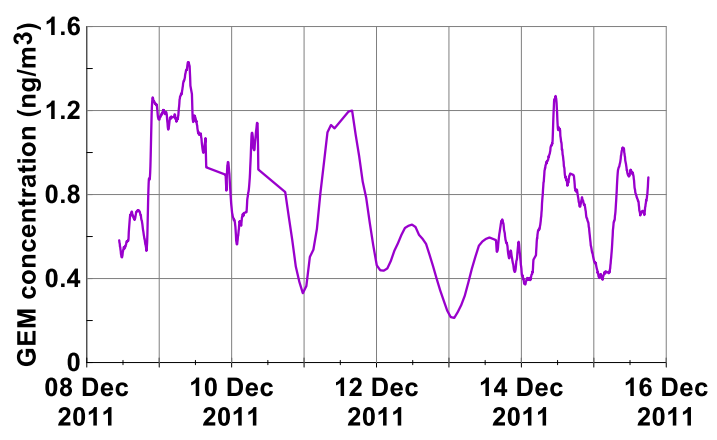

Fig 4: Illustration of daily cycling of $\operatorname{Hg}(0)$ in December

\section{Conclusion}

The monitoring of $\operatorname{Hg}(0)$ at Dome Concordia has already shown some unique results and a surprising level of reactivity. Oxidation processes exists on the Antarctic
Plateau however the oxidants that are involved remain unclear. Snow reemission of $\mathrm{Hg}(0)$ by photochemistry are important processes as well that can influence the $\mathrm{Hg}(0)$ measured in the overlying boundary layer. We suspect that the strong dynamic prevail during spring and summer while winter months will show more stable values. These trends will be confirmed as we continue to develop a longer data set.

\section{Acknowledgements}

This work contributes to the EU-FP7 project Global Mercury Observation System (GMOS). Logistical support and financial support were also provided by the French Polar Institute IPEV (Program 1028, GMOStral). We want to acknowledge the Project ANR-07-VULN-013 VANISH that provided technical support. We are very grateful to Gregory Teste and Laurent Arnaud. We thank the winterovering technical staff (Sébastien Aubin). AD is grateful to the Institut Universitaire de France.

\section{References}

Arimoto R, Schloesslin C, Davis D, Hogan A, Grube P, Fitzgerald W, Lamborg C. Lead and mercury in aerosol particles collected over the South Pole during ISCAT-2000. Atmos. Environ. 2004;38:5485-5491.

Brooks S, Arimoto R, Lindberg S, Southworth G. Antarctic polar plateau snow surface conversion of deposited oxidized mercury to gaseous elemental mercury with fractional long-term burial. Atmos. 
Environ. 2008a;42:2877-2884.

Brooks S, Lindberg S, Southworth G, Arimoto R. Springtime atmospheric mercury speciation in the McMurdo, Antarctica coastal region. Atmos. Environ. 2008b;42:2885-2893.

Davis DD, Seelig J, Huey G, Crawford J, Chen G, Wang Y, Buhr M, Helmig D, Neff W, Blake D, Arimoto R, Eisele F. A reassessment of Antarctic plateau reactive nitrogen based on ANTCI 2003 airborne and ground based measurements. Atmos. Environ. 2008;42:2831-2848.

Dommergue A, Bahlmann E, Ebinghaus R, Ferrari C, Boutron C. Laboratory simulation of $\mathrm{Hg}^{\circ}$ emissions from a snowpack. Anal. Bioanal. Chem. 2007;388:319-327.

Dommergue A, Barret M, Courteaud J, Ferrari CP, Cristofanelli P. Dynamic cycling of $\mathrm{Hg}(0)$ inside the Antarctic Plateau boundary layer. submitted to Atmospheric Chemistry and Physics Discussions 2012;

Dommergue A, Sprovieri F, Pirrone N, Ebinghaus R, Brooks S, Courteaud J, Ferrari CP. Overview of mercury measurements in the Antarctic troposphere. Atmos. Chem. Phys. 2010;10:3309-3319.

Ebinghaus R, Kock HH, Temme C, Einax JW, Löwe AG, Richter A, Burrows JP, Schroeder WH. Antarctic Springtime Depletion of Atmospheric Mercury. Environ. Sci. Technol. 2002;36:1238 -1244.

Eisele F, Davis DD, Helmig D, Oltmans SJ, Neff W, Huey G, Tanner D, Chen G, Crawford J, Arimoto R, Buhr M, Mauldin L, Hutterli M, Dibb J, Blake D, Brooks SB, Johnson B, Roberts JM, Wang Y, Tan D, Flocke F. Antarctic Tropospheric Chemistry Investigation (ANTCI) 2003 overview. Atmos. Environ. 2008;42:2749-2761.

Faïn X, Ferrari CP, Dommergue A, Albert M, Battle M, Arnaud L, Barnola JM, Cairns W, Barbante C, Boutron C. Mercury in the snow and firn at Summit Station, Central Greenland, and implications for the study of past atmospheric mercury levels. Atmos. Chem. Phys. 2008;8:3441-3457.
Jitaru P, Gabrielli P, Marteel A, Plane JMC, Planchon FAM, Gauchard PA, Ferrari CP, Boutron CF, Adams FC, Hong S, Cescon P, Barbante C. Atmospheric depletion of mercury over Antarctica during glacial periods. Nature Geosci. 2009;2:505-508.

Obrist D, Tas E, Peleg M, Matveev V, Fain X, Asaf D, Luria M. Bromine-induced oxidation of mercury in the mid-latitude atmosphere. Nature Geosci. 2011;4:22-26.

Selin NE, Jacob DJ, Park RJ, Yantosca RM, Strode S, Jaegle L, Jaffe D. Chemical cycling and deposition of atmospheric mercury: Global constraints from observations. J. Geophys. Res. 2007;112:D02308, doi:02310.01029/02006JD007450.

Sprovieri F, Pirrone N, Ebinghaus R, Kock H, Dommergue A. A review of worldwide atmospheric mercury measurements. Atmos. Chem. Phys. 2010;10:8245-8265.

Sprovieri F, Pirrone N, Hedgecock IM, Landis MS, Stevens RK. Intensive atmospheric mercury measurements at Terra Nova Bay in Antarctica during November and December 2000. J. Geophys. Res. 2002;107:4722.

Steffen A, Douglas T, Amyot M, Ariya P, Aspmo K, Berg T, Bottenheim J, Brooks S, Cobbett F, Dastoor A, Dommergue A, Ebinghaus R, Ferrari C, Gardfeldt K, Goodsite ME, Lean D, Poulain AJ, Scherz C, Skov H, Sommar J, Temme C. A synthesis of atmospheric mercury depletion event chemistry in the atmosphere and snow. Atmos. Chem. Phys. 2008;8:1445-1482.

Temme C, Einax JW, Ebinghaus R, Schroeder WH. Measurements of Atmospheric Mercury Species at a Coastal Site in the Antarctic and over the South Atlantic Ocean during Polar Summer. Environ. Sci. Technol. 2003;37:22-31.

Vandal GM, Fitzgerald WF, Boutron CF, Candelone J. Variations in mercury deposition to Antarctica over the past 34000 years. Nature 1993;362:621-623. 